\title{
最近の循環冷却水処理について
}

\author{
山本大輔 \\ *栗田工業株式会社総合研究所

\section{Modern Cooling Water Treatment} \\ Daisuke Yamamoto* \\ *Kurita Water Industries Ltd. Kurita Central Laboratories
}

\begin{abstract}
The history of open recirculating cooling water treatment and recent "Alkaline Treatment" were described. In high concentration of Ca-hardness and $\mathrm{M}$-alkalinity solution, $\mathrm{CaCO}_{3}$ deposition was controlled by the addition of scale inhibitors such as phosphonates or polyelectrolytes and the corrosion of mild steel was also prevented by small amount of $\mathrm{PO}_{4}$.
\end{abstract}

\section{1. 緒言}

我が国に打ける冷却塔循環水の水処理の歴史は, 1960 年当時, 石油化学の発祥とともに始市り, 幾多の変遷を 経過してきた。すなわち石油化学工業の発展は, プラン トの大型化和よび操業率の向上をめざし，これに対応す るために水処理薬剤は効果の追求が行われた。次いで水 資源を有効に利用しようという見地から，循環水の濃縮 倍数を高く保つ, いわゆる高濃縮運転が普及し, さらに 最近では, 環境污染防止対策の上から, 水処理薬品の選 定にも充分な配慮がなされなければならなくなってい る。

ここでは循環水の水処理, とくに腐食およびスケール 生成の防止に焦点をあて，その発展の歴史について解説 するとともに, 最近普及しつつある循環水の“アルカリ 処理”について, 実験例をもとに少し詳しく紹介したい。 な拉本稿と関連して, 鈴木 ${ }^{1)}$ の解説を参照していただき たい。

\section{2. 循環水処理の歴史}

鈴木 ${ }^{1)}$ は, インヒビター执よび関連技術の発展の歴史 を, 日本和よびアメリカと対比させ, 研究開発の終了点 でとらえて年表としてまとめているが，ここでは年代を 追って，実際にどのような処理が行われたかについて述 ベたいと思ら。

\section{$2.11960 \sim 1965$ 年}

1960 年当時, すなわち石油化学の誕生の頃は, まだ プラントの視模も小さく, 一過式の冷却方式を採用して

* 干240 横浜市保土谷区仏向町 1723 (1723, Bukkocho, Hodogaya-ku, Yokohama, 240 Japan)
いる工場が多かったが，冷却塔をもら循環方式を採用し ている場合には, 濃縮倍数も 1.5 倍程度と低く, インヒ ビターとしてはポリリン酸塩系のものが使用されてい た。ポリリン酸塩は, 金属に対するキレート力や析出抑 制能が強いなど，水処理薬剂としてすぐれた特性がある ことは古くから知られて括り，また亜鉛，カルシウムお よびニッケルなどの二価金属が共存すると，すぐれた防

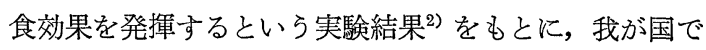
はへキサメタリン酸ナトリウムと亜鉛塩を併用する方法 が一般に採用されていた。しかし当時は，(1)インヒビタ 一の濃度, 添加方法や制限水質を規定する使用基準が明 確に定められていなかったため，インヒビターの特性を 十分に発揮させえなかったこと, (2)スライムコントロー ルやスケール生成防止技術が未熟であったため，スライ ムやスケール付着に起因して発生する二次的な腐食をイ ンヒビターの効果の不十分さと評価されたなどの理由か ら,ポリリン酸塩系インヒビターの評判は, 必ずしも芳 しくなかった。 その後, 石油化学工業はスケールメリットを求めて, プラント規模は大型化し, また操業率を高める方策が進 められ，それにともない水処理薬品も，いっそら効果の 高いものが要求されるようになった。

このよらな状況に対応するために, クロム酸塩系イン ヒビターの検討が行われた。クロム酸塩はポリリン酸塩 と併用すると, 水質や運転条件による効果の変動が少 く3), 卓越した効果を示すことが認められ，またスライ ムコントロール技術も進歩して, この種のインヒビター の利用は, 1965 年頃までに急速に広まっていった。 
工業の拡大とともに地域によって, 工業用水は不足す る傾向を示し，また循環冷却水の排出水に含まれるク口 ム酸塩による環境污染が問題となり，循環水の処理方式 について見直しが必要になってきた。

工業用水を節減するために, 循環水の排出水量を減少 させる，いわゆる高濃縮循環水処理が検討されるように なった。高濃縮循環水処理を行らと, 循環水中のカルシ ウムイオンや重炭酸イオン (Mアルカリ度) が高くなり, 熱交換器など水温の高い部分では炭酸カルシウムスケー ルの生成による伝熱障害の問題が発生する。また高濃縮 処理の条件では, 循環水中に括けるインヒビタ一の滞留 時間は長くなり，ポリリン酸塩のように化学的に安定で ない物質を使用することには問題がある。

そこで炭酸カルシウムスケールの生成を防止するため に, 循環水に酸を添加して $\mathrm{M}$ アルカリ度を低下させ, $\mathrm{pH}$ 6.5 7.0 程度に調整する方法が取られ，またイン ヒビターとしてクロム酸塩 亜鉛塩系のものが採用され るようになった。このインヒビターはとくに伝熱面で顕 著な効果を示すことが知られている4)。

高濃縮循環水処理は，水使用量を節減するために開発 されたが，排出水量を減少させて運転することから，排 出するクロム酸の総量を低減させ環境污染防止対策上も 利点があり注目を浴びるところとなった。たとえば 2 倍 濃縮と 5 倍濃縮の運転では, 排出水の量は $1 / 6 \sim 1 / 10$ 程 度となり，排出水中に含まれるクロム酸塩をイオン交換 樹脂で回収する方法 ${ }^{5)}$ や還元処理する方法も実用の対象 となるようになった。

\section{$2.31970 \sim 1974$ 年}

1970 年 4 月, 環境基準に $\mathrm{Cr}^{8+}$ は $0.05 \mathrm{ppm}$ 以下と定 められ，さらに排出基準で排水中の $\mathrm{Cr}^{6+}$ は $0.5 \mathrm{ppm}$ 以 下と規制されて以来，インヒビターとしてクロム酸塩系 のむのを使用することは事実上困難となった。そこで多 くのプラントで, 非クロム酸塩系インヒビターへの転換 が積極的に検討されたわけである。初期においては,リグ ニンスルホン酸など天然有機化合物を主㓮とするものな ぞ，多品種のものが検討の対象となったが，それらの大 部分は効果が不十分であったため，残されたものは過去 に使用されたポリリン酸塩系インヒビターの見直しとい ら形で非クロム酸塩への転換がはかられていった。この 時代では，1960年当時と比較すると使用基準も明確にな り，不測のトラブルを起こす事例は少くなったものの， ポリリン酸塩の性能的限界として高温部におけるリン酸 カルシウムスケールの生成が課題として残された。また ポリリン酸塩は加水分解してオルソリン酸になるため, 滞留時間の長い高濃縮処理には不適当であり, 高濃縮に 耐光る非ク口ム酸塩による処理法の開発が強く要望され た。

\section{$2.41975 \sim 1976$ 年}

最近になってリン酸カルシウムの析出抑制に顕著な効 果を示すスケール防止肪が開発されて，さきに述べたポ リリン酸塩系インヒビターを使用して問題となった高温 部におけるスケール生成の問題は，ほぼ解決されるよう になった。

一方高濃縮循環水処理の方法としてアルカリ処理が実 用期に入っている。少量のポリリン酸塩が炭酸カルシウ ムの結晶析出を抑制することは古くから知られていた が，(1濃縮倍数の低い場合には，炭酸カルシウムスケー ル生成の障害は，ほとんど起こらないこと，(2)また炭酸 カルシウムの析出が問題となるような高濃度の系では, ポリリン酸塩の加水分解率が高くなるため, これをスケ 一ル防止剂として適用することには問題があるなどの理 由から，ポリリン酸塩をスケール防止剤として実用的な 利用に関する検討はあまり行われていなかった。しかし 近年になってポリリン酸塩と類似した特性を有し，しか も化学的に比較的安定なホスホン酸が開発され, 冷却水 処理剤としての適用研究が行われるようになった。

従来は高濃縮偱環水処理を行う場合, 循環水の $\mathrm{pH}$ を 弱酸性に保ち，インヒビターを添加することによってス ケール拉よび腐食障害に対処していた。これに対してア ルカリ処理すなわち， $\mathrm{pH}$ 制御を行わずに濃縮倍数を上 昇させて循環水を弱アルカリ性とし, むしろ炭酸カルシ ウムの析出が可能となる水質とし(このような水質では, 金属は腐食しにくい), 炭酸カルシウムの析出をホスホ ン酸および高分子電解質で抑制する方法が注目されはじ めた。以下にアルカリ処理に関する実験例のいくつかを 挙げ解説する。

\section{3. アルカリ処理 ${ }^{6)}$}

\section{1 炭酸カルシウム析出の抑制}

Fig. 1 はカルシウム硬度および重炭酸イオン $(M$ アル カリ度)がそれぞれ $250 \mathrm{ppm}$ の溶液にホスホン酸および 高分子電解質*を添加した場合の炭酸カルシウム析出抑 制率を示したものである。このような高濃度のスケール 成分を含む溶液に，少量の析出抑制剂を添加したとき， 析出が抑制される現象を一般に threshold 効果と呼んで いるが，抑制機構についてはまだ充分には解明されてい ない。しかし Fig. 2 抢よび Fig. 3 に示すように，抑 制剂無添加の場合と比較して, 完全抑制領域以下の添加 濃度で析出する炭酸カルシウムの結晶は大きな歪を受け て和り, 結晶の析出過程で炭酸カルシウムの表面へのホ スホン酸または高分子電解質の吸着が結晶の成長を阻害 するのではないかと考觉らる。

* 商品名クリゼット S-110 


\section{2 湮縮水中における軟鋼の腐食}

横浜市水㧍よびこれを 5 倍に濃縮した水の詹食性の差 異を調べるために回転円板法による腐食試験を行った。

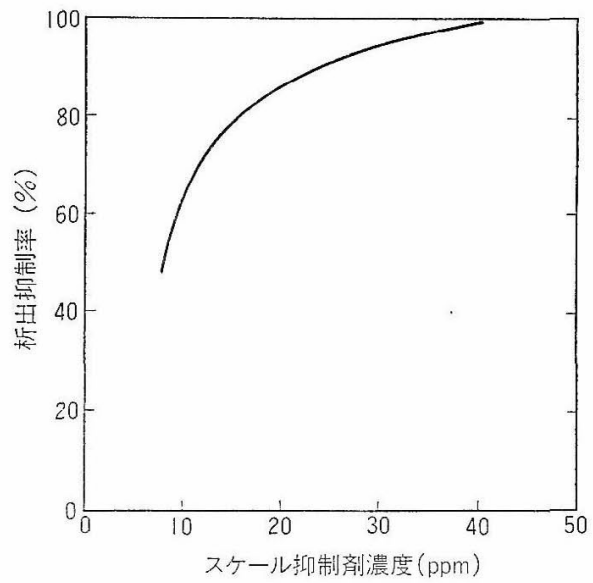

Fig. 1. スケール抑制剂による $\mathrm{CaCO}_{3}$ 析出抑制効 果

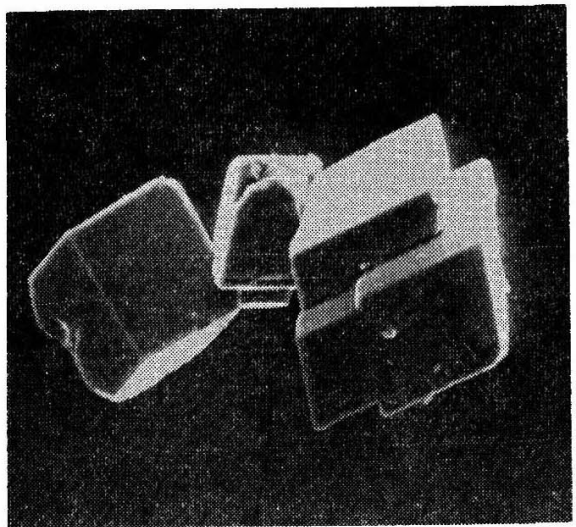

Fig. 2. スケール防止剂無添加の場合に生成する炭 酸カルシウム

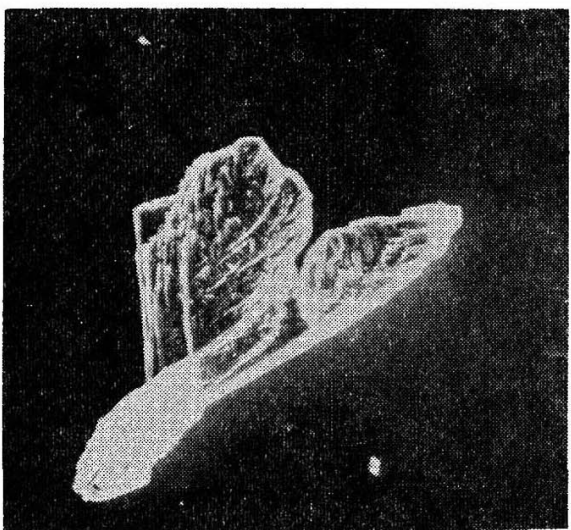

Fig. 3. スケール防止剂を微量添加した場合飞生成 する炭酸カルシウム
試験液の組成を Table 1 亿, 試駼結果を Fig. 4 亿示す。 横浜市水の場合には，軟鋼の腐食減量注数の経過と ともに直線的に增大し，20日間で約 $5,000 \mathrm{mg} / \mathrm{dm}^{2}(250$

表 1 横浜市水および濃縮水の水質分析值

\begin{tabular}{|c|c|c|c|}
\hline & & 横浜市水 & 濃 縮 水 \\
\hline & $\mathrm{pH}$ & 7.4 & 8.2 \\
\hline 電 & 率 $(\mu \mho / \mathrm{cm})$ & 282 & 928 \\
\hline Mアルカリ度 & 度 ( $\mathrm{ppm}$ as $\mathrm{CaCO}_{3}$ ) & 42 & 248 \\
\hline 全硬度 & 度 (ppm as $\mathrm{CaCO}_{3}$ ) & 70 & 351 \\
\hline カルシウム硬度 & 度 (ppm as $\mathrm{CaCO}_{3}$ ) & 46 & 258 \\
\hline 塩素イオン & ン (ppm) & 19 & 71 \\
\hline 硫酸イオン & ン (ppm) & 24 & 257 \\
\hline リ & 力 $(\mathrm{ppm})$ & 21 & 41 \\
\hline
\end{tabular}

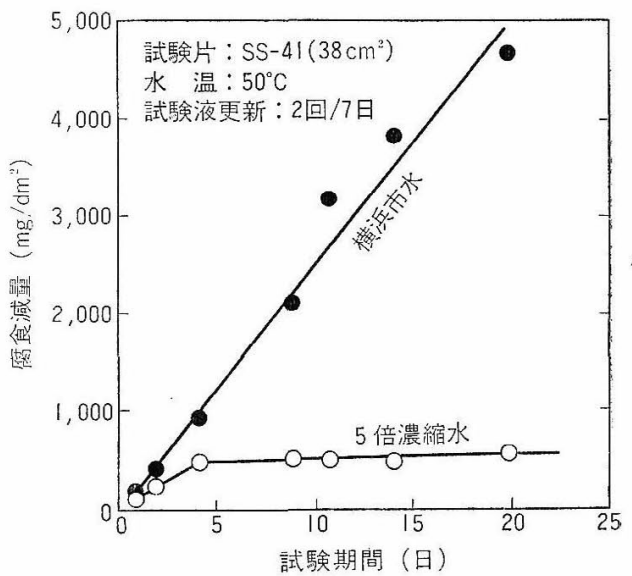

Fig. 4. 軟鋼の詹食に及汪す水質の影響

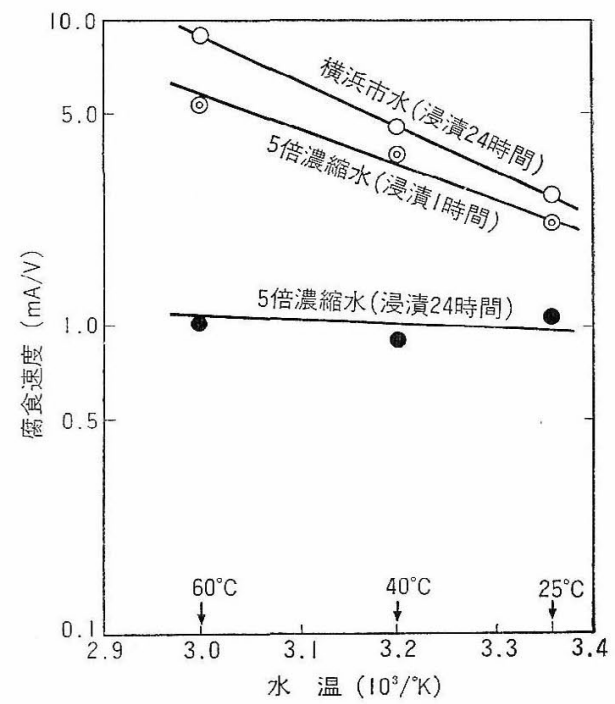

Fig. 5. 横浜市水和よび濃縮水中に扔ける軟鋼の腐 食速度と水温の関係 
$\mathrm{mg} / \mathrm{dm}^{2}$ ·day) の腐食を示したのに対し，5 倍濃縮水で は，時間の経過とともに腐食は抑制され，20日間の腐食 減量は約 $600 \mathrm{mg} / \mathrm{dm}^{2}\left(30 \mathrm{mg} / \mathrm{dm}^{2}\right.$ ·day) となった。また この場合, 試験液のカルシウム硬度および M アルカリ 度は，それぞれ約 $100 \mathrm{mg}$ 減少したこと抢よび腐食試験 後の試験片を塩酸に浸漬して脱錆すると激しく発泡し, 炭酸ガスを発生することから, 濃縮水中では試験片表面 に炭酸カルシウムが析出し, その結果として腐食が低減 したものと思われる。

この結果の実用面への適用法について考察してみる。 まず冷却系全体に用水を満たし運転が開始されるが，冷 却水の濃縮は徐々に起こるので, この過程で腐食は進行 すると考兄られる。濃縮倍数が十分高くなり，腐食が軽 減するに到るまでの過渡期間の腐食を抑制するために, インヒビターの基碟投入が必要になる。

次に回転電極装置を用いて，軟鋼の腐食速度に与える 温度の影響を調べた。Fig. 5 に示したように横浜市水 (浸漬 24 時間後) お。び浸漬 1 時間後の 5 倍濃縮水の場 合，腐食速度は温度によって影響されることがわかる。 これに対して浸漬 24 時間後の濃縮水中では， $25 \sim 60^{\circ} \mathrm{C}$ の範囲で腐食速度の変化は汪とんぞ認められず，また前 2 者と比較してその值も小さいことがわかった。これは Fig. 4 亿示したように，濃縮水の場合でも，初期にはか なりの腐食があるが，時間の経過とともに腐食速度が減 少することと良く一致している。

次に回転速度を変化させた場合，Fig. 6 に示すように 濃縮水中に打ける軟鋼の腐食速度は，浸漬 1 時間後の測 定では，回転速度の平方根に比例して著しい上昇が見ら れたが，浸漬 24 時間では回転数による影響をあまり受 けなかった。

以上の結果から，横浜市水中に抹ける軟鋼の腐食速度

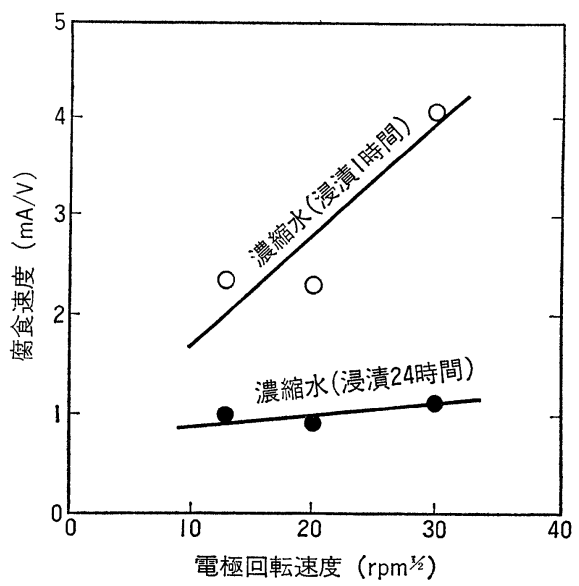

Fig. 6. 濃縮水中にお沙る軟鋼の腐食速度と電極回 転速度の関係
は，カソード反応物質である溶存酸素の溶液中に打㳊る 拡散速度に律速されているものと考兄られた。一方濃縮 水中に护ける軟鋼の腐食は，浸漬の初期段階では，横浜 市水と同様に，溶存酸素の溶液中に打ける拡散に律速さ れて進行するが，時間の経過とともに温度にも回転数に むあまり影響を受けない状態に到る。これは軟鋼表面上 に炭酸カルシウムなど，腐食を抑制する沈殿皮膜が形成 され，反応の律速過程が反応物質の溶液中の拡散から， 沈殿皮膜内の拡散に変化したとして説明できる。

\section{3 濃縮水中におけるインヒビターの効果}

カルシウム硬度および M アルカリ度をそれぞれ 250 ppm に調整した試験液掞よびこれに炭酸カルシウム析 出抑制剂として高分子電解質を添加して軟鋼の腐食減量 の経時変化を求めた。Fig. 7 亿示すように高分子電解質 を含まない場合には，先に示した横浜市水の 5 倍濃縮水 の場合と同様に，時間の経過とともに腐食速度が減少す ることがわかる。

これに対して高分子電解質を添加した試験液では，腐 食減量は時間の経過とともに直線的に増加してゆく。こ の結果は, 腐食性の弱い高硬度, 高Mアルカリ度の試験 液を用いても，炭酸カルシウムの析出を抑制すると腐食 性は增大することを示している。しかしこのような溶液 でも，インヒビターを併用添加により腐食速度を低減さ せうる可能性があると考光，カルシウム硬度およびMア ルカリ度を種々の濃度に変化させ，これに高分子電解質 およびリン酸系インヒビターを添加して腐食試験を行っ た。Fig. 8 はカルシウム硬度，Mアルカリ度が低い場合 (ともに $50 \mathrm{ppm}$ )，腐食を抑制するためには $9 \mathrm{ppm} の$ $\mathrm{PO}_{4}$ を必要としたのに対し, カルシウム硬度, $\mathrm{M}$ アル カリ度が高くなるに従って $\mathrm{PO}_{4}$ 限界濃度は極度に低下

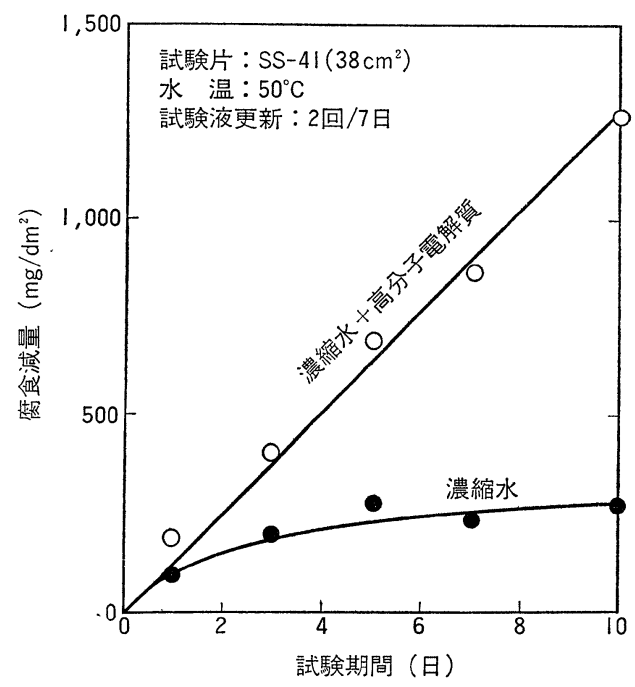

Fig. 7. 軟鋼の腐食に及洔す高分子電解質の影響 


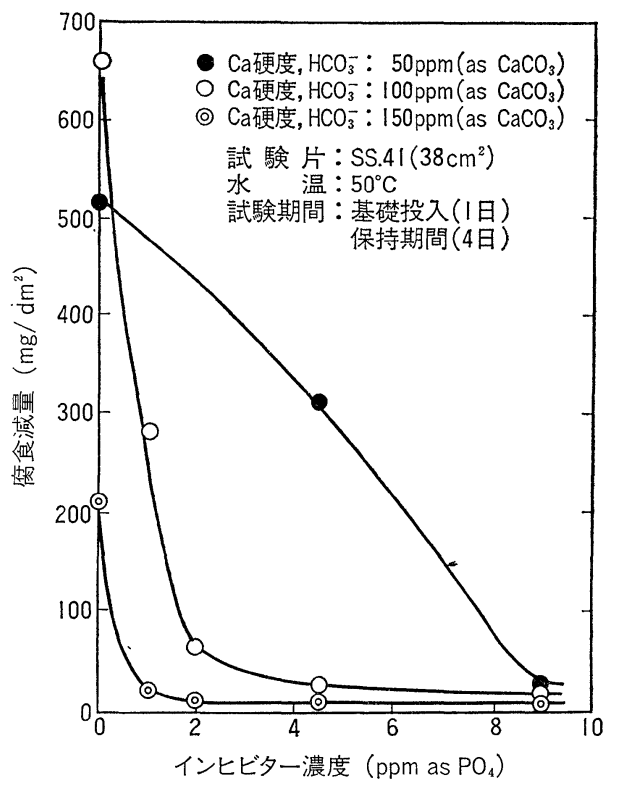

Fig. 8. リン酸系インヒビターの防食効果に及洔す $\mathrm{Ca}$ 硬度, $\mathrm{HCO}_{3}{ }^{-}$の影響

することを示している。

以上の結果から, 循環水の濃縮倍数を高く保ち, 炭酸 カルシウムの析出を高分子電解質あるいはホスホン酸で 抑制しまた低濃度りン酸イオンで腐食を抑制すること が可能である。

\section{4. 結 言}

我が国に拈ける冷却塔循環水処理の歴史は，その初期
に乱いて効果と経済性の追求が行われてきた。その経過 として高濃縮冷却水処理用のインヒビターとしてクロム 酸〜亜鉛系のものが完成されたわけであるが，環境污染 防止対策として高濃縮用非ク口ム酸塩系処理への転換が 強く要望されてきた。ホスホン酸拉よび高分子電解質が 高濃縮水中に拈いて炭酸カルシウムの析出を抑制するこ と拉よび少量のリン酸が，このような条件下で腐食抑制 効果を示すことが明らかになった。従来のポリリン酸塩 系インヒビターは, 通常 10 15 ppm (as $\left.\mathrm{PO}_{4}\right)$ の濃度で 使用されていたのに対し，この方法では数 ppm で処理 が可能であり，乙か子排出水量を従来法の 1/2 1/4 に することができることから，環境污染防止上はもとより 資源の有效利用上有意義なるのがあると考穴られる。な おこのアルカリ処理法は，多くのプラントに適用され， 長いものは 3 年の実績を有し, いずれもが実験室で得ら れたデータと同様の結果を示していることを付記する。

\section{文献}

1）鈴木 隆：防食技術，23，No. 4, 197 (1974).

2) 竹内康三: 防蝕技術, 8, No. 4, 5 (1959).

3）鈴木 隆, 中川二朗, 村野寬治, 山本大輔：防 蝕技術, 17, No. 8, 322 (1968).

4) 山本大輔, 鈴木 隆, 守永日出夫：防食技術, 24, No. 6, 283 (1975).

5) 山本大輔, 矢部江一, 安倍 脩, 織田信博: 石 油学会誌, 18, No. 4, 284 (1975).

6) D. Yamamoto, T. Suzuki: Proceedings of 4th European Symposium on Corrosion Inhibitors (1975). 